\title{
Testicular Embryonal Carcinoma
}

National Cancer Institute

\section{Source}

National Cancer Institute. Testicular Embryonal Carcinoma. NCI Thesaurus. Code C6341.

A malignant germ cell neoplasm arising from the testis. It is composed of primitive epithelial cells arranged in solid, papillary, and glandular configurations. Most patients present with a testicular mass, which may be associated with pain. More than half of the patients have metastatic disease at diagnosis. The form of treatment following radical orchiectomy is stage dependent. 